Prof. Aleksandar $\check{C} U D A N, P h D^{*}$

University of Criminal Investigation and Police Studies

Đurica NIKOLIĆ ${ }^{* *}$

Customs Administration of the Republic of Serbia, Customs Office Nis Prof. Dalibor KEKIĆ, PhD ${ }^{* * *}$

University of Criminal Investigation and Police Studies

DOI: $10.5937 /$ bezbednost2001121C

UDK:336.71:004.738.5::004.056(497.11)

Pregledni naučni rad

Primljen: 3. 9. 2019. godine

Revizija: 8. 12. 2019.godine

Revizija: 26. 2. 2020.godine

Datum prihvatanja: 7. 4. 2020. godine

\title{
New Architecture and Risks in Payment Card Operations
}

\begin{abstract}
Digitalization in all spheres of social life, widespread distribution and numerouspossibilities of smart phones as well as increasing amounts and scope of electronic contents and services lead to the emergence of new expectations and new requirements of banks, buyers and sellers, which refer to contemporary architecture of payment card operations. Payments make integral part of business operations regardless of whether we talk about traditional or on-line business operations, and this is why it is necessary to find the best manner to pay for goods or services using new technological and communications solutions. The subject of research in this paper is the analysis of characteristics of contemporary risks, development factors, economic effects and distribution of payment cards within the system of e-money, e-payment and e-banking, with a view to indicating the possible positive economic consequences and necessity to innovate and complete legal regulations in this area.
\end{abstract}

The paper uses both general and specific scientific methods and procedures of logical conclusion, statistical, as well as positivist legal

\footnotetext{
*aleksandar.cudan@kpu.edu.rs

**d.nikolic@gmail.com

***dalibor.kekic@kpu.edu.rs
} 
method. The manner of research includes the selection and application of scientific methods, the selection of data and the scope of research.

Keywords: payment cards, risk, payment, security

\section{Introductory remarks}

The main characteristic of contemporary world trends, including the financial world and the payment industry, is to develop new, although not always better forms of business operations. Developing new forms of payment and business operations is one of the most common characteristics of the contemporary financial world. When defining the term new architecture of card operations, we primarily think of their innovativeness, the capability to adapt to new technological challenges, as well as their contemporary role within the e-payment system, considering that today there are over three hundred modalities of e-payment.

Payment card is a payment instrument issued by a bank, a payment institution or a legally authorisedorganization, which makes it possible to users to dispose of their assets on the account, in other words to pay for goods and services or to withdraw cash, or do any other operation related to the assets on the account (PrivrednakomoraSrbije, 2018: 8). The basis of a payment card is an order for a certain amount of money to be paid or paid out to a user, to be transferred or the holder's order which refers to some other specific characteristic of a card.

Methodology used by the National Bank of Serbia (NBS) in the second decade of a new millennium when publishing the data on payment cards is substantially different in comparison with previous years since it is adapted to the statistics of the payment services based on the Law on Payment Services. ${ }^{1}$ At the same time, this statistics includes the data on the number of cards with the function of e-money and the transactions carried out at the Internet with this money. Business cards are not included in the statistics of the NBS. This is

\footnotetext{
${ }^{1}$ According to the Decision on the content, terms and manners of submitting data which the card service providers send to the NBS (Official Gazette of the Republic of Serbia no. 57/2015 and 57/2015 - correction), the accent in collecting and processing the data by the NBS is on the functions the payment cards have in payment operations.
} 
why some data which are usually included in annual analyses of the payment card market are not completely comparable with previous years. This is the reason why it should bear in mind that some data presented in this scientific paper can differ from the exact data, but these discrepancies generally do not deform substantially the presented trends and values which are the subject of research. ${ }^{2}$

\section{Distribution of Payment Cards in E-Payment System of the Republic of Serbia}

A considerable number of card brands and technological architecture of these systems improve the quality of life and play the crucial role in modern economic environment. Although over seventy years have passed since the first payment card appeared and although it is the fact that as of recently they have been written about as the trend of the future, it is today already that this becomes a conceptual technological standard. Contemporary payment operations and transaction mechanisms in banking in Serbia cannot simply be imagined without a considerable participation of payment cards (Granville, 2017: 28). Spreading and expansions of these contemporary e-payment instruments depend primarily on the interest of the banks and their clients (Končar, 2008: 311).

Winding up traditional branch offices anddiscontinuingthe work with bank clerks is only one but more and more present sign of 'modern digital era' which the mankind has entered (Lazović, Đurović, 2018: 17). Expert financial analyses and technological expertise in recent years more and more often lead to elimination of paper money and transition to e-money. Theorists of the future predict that very soon we will be in a situation to use e-money only, that all kinds of shopping or payments will be made using credit and payment cards, instant payments and this is simply inevitable, as financial experts say, and add that the mentioned systems would not come into use that easily since more than $85 \%$ of population worldwide are financially illiterate and apart from basic payment operations or purchases they do

\footnotetext{
${ }^{2}$ The paper is the result of research project "Crime in Serbia and Instruments of State Response", financed and implemented by the University of Criminal Investigation and Police Studies, cycle of scientific research 2015/2019.
} 
not know or understand anything else - particularly not about finances or monetary policies.

Table 1. Number of payment cards issued in the Republic of Serbia

\begin{tabular}{c|c|c|c}
\hline Year & $\begin{array}{c}\text { Number of payment } \\
\text { cards issued in the } \\
\text { Republic of Serbia }\end{array}$ & $\begin{array}{c}\text { Number of payment cards } \\
\text { active in the Republic of } \\
\text { Serbia }\end{array}$ & $\%$ \\
\hline 2001 & 2 & & \\
\hline 2002 & 400000 & & \\
\hline 2003 & 500000 & & \\
\hline 2004 & 2100000 & & \\
\hline 2005 & 3800000 & & \\
\hline 2006 & 5240000 & & 48 \\
\hline 2007 & 5725465 & & 48 \\
\hline 2008 & 5728789 & 2944458 & 46 \\
\hline 2009 & 6014390 & 3073282 & 47 \\
\hline 2010 & 6150000 & 2737873 & 49 \\
\hline 2011 & 6350587 & 2922597 & 51 \\
\hline 2012 & 5934784 & 3073646 & 57 \\
\hline 2013 & 6207833 & 3262106 & 54 \\
\hline 2014 & 6267058 & 3931496 & 55 \\
\hline 2015 & 6454356 & 3970034 & \\
\hline 2017 & 6900997 & 4312557 & \\
\hline 2018 & 7342677 & & \\
\hline $501769:$ & 7778958 & & \\
\hline
\end{tabular}

Source: National Bank of Serbia, Monetary system and policy department, based on bank reports

Based on the statistical data of the central monetary institution of Serbia, the number of debit and credit cards issued in 2018, when compared with 2014 , increased by $19.55 \%$, in other words from 6,267058 to 7,778958 or by 1,511908 cards. In comparison with the same periods of observation, the number of active debit and credit cards increased from 3,073646 to $4,312,557$, i.e. by $40.30 \%$. In other words, at the end of 2018, there were nearly 1,238 911 active cards more than during 2014 (the percentage of active cards in comparison with the cards issued in the entire period stabilised at nearly 55\%). The number of issued cards increased evenly, while the number of active 
cards stagnated in 2017, and then increased distinctively during 2018. It is important to mention that debit cards actually boosted the increase in the number of active cards.

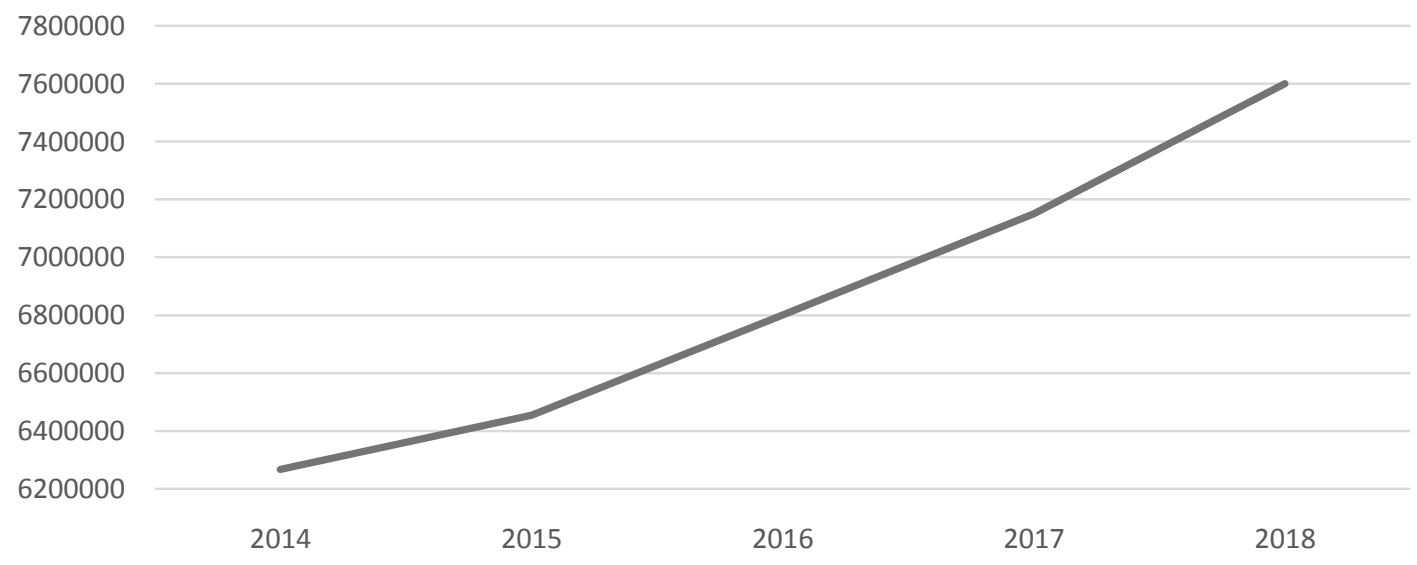

Figure 1: Number of debit and credit cards in the Republic of Serbia.

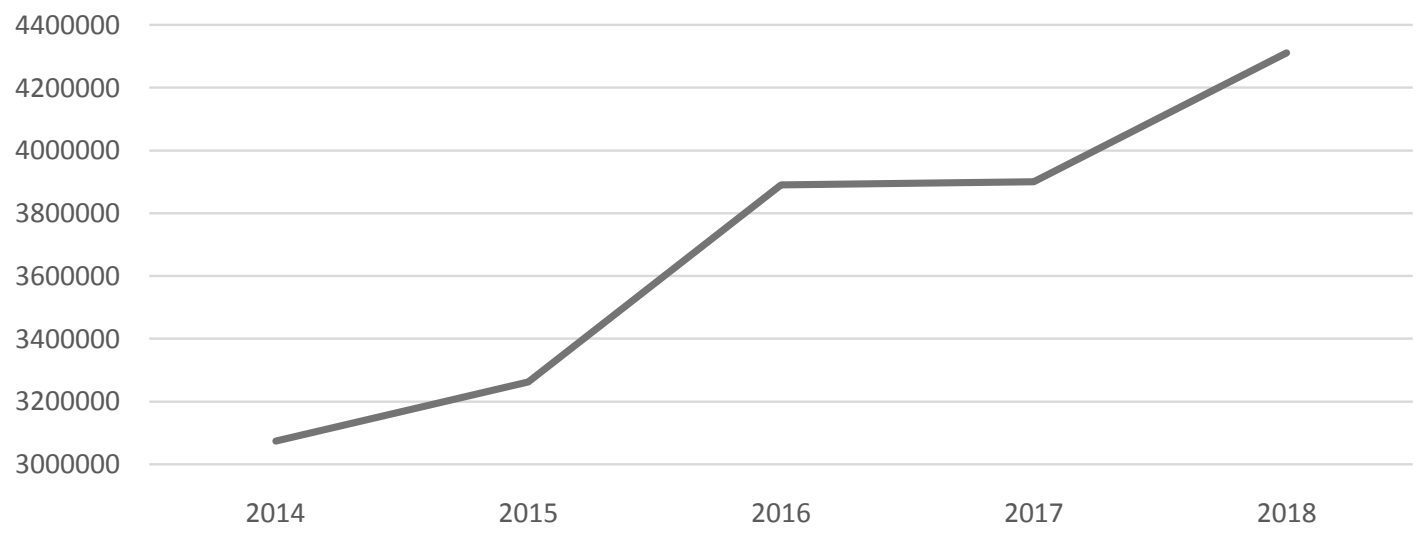

Figure 2: Number of active debit and credit cards in the Republic of Serbia.

Distribution of the acceptance network does not record similar trends. The number of ATMs(Automated Teller Machine) stagnates 
from 2,983 to 2,848, while the number of POSs considerably decreased in 2017 and then recovered during 2018.

The existing card acceptance network in Serbia in comparison with the countries in the region is still relatively well developed. Starting from 2014, after a few years, the first increase of ATMs was recorded, which is a rather important news considering that their number was constantly decreasing in the period from 2010 to 2014 . This trend of increase continued and in the end of 2016 there were 2,845 ATMs, which then drastically dropped during 2017, and then the trend of increase of ATMs was again recorded during 2018. Considering that the number of branch offices decreased and the number of branch offices working in the afternoon is increasingly smaller, it is evident that these trends are not followed by the increase of the number of ATMs.

2983

3000

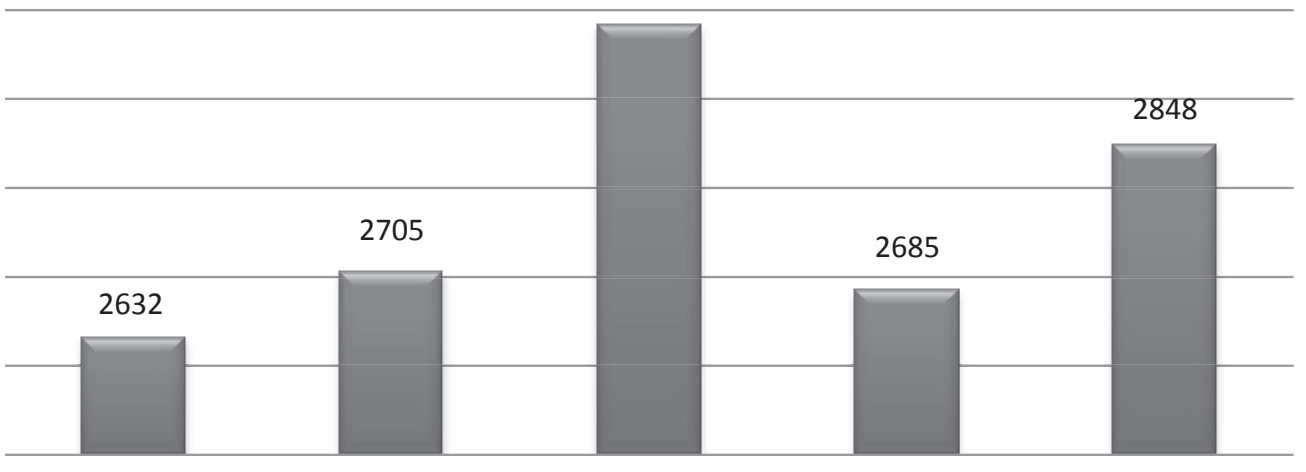

2014

2015

2016

2017

2018

Figure 3. ATM (Automated Teller Machine) $)^{3}$

At the end of 2014 there were 64,142 POS terminals and in the following years the increasing trend continued in comparison with the previous years. During 2018 the increase of POS terminals number was far larger than in previous years and was $27.1 \%$. It is necessary to

\footnotetext{
${ }^{3}$ An automated teller machine is a computerized telecommunications device that is used by card holders for cash withdrawals.
} 
bear in mind that this is not a realistic increase of acceptance network but primarily a consequence of various methodology in presenting the number of POS terminals in points of sale - retail. ${ }^{4}$

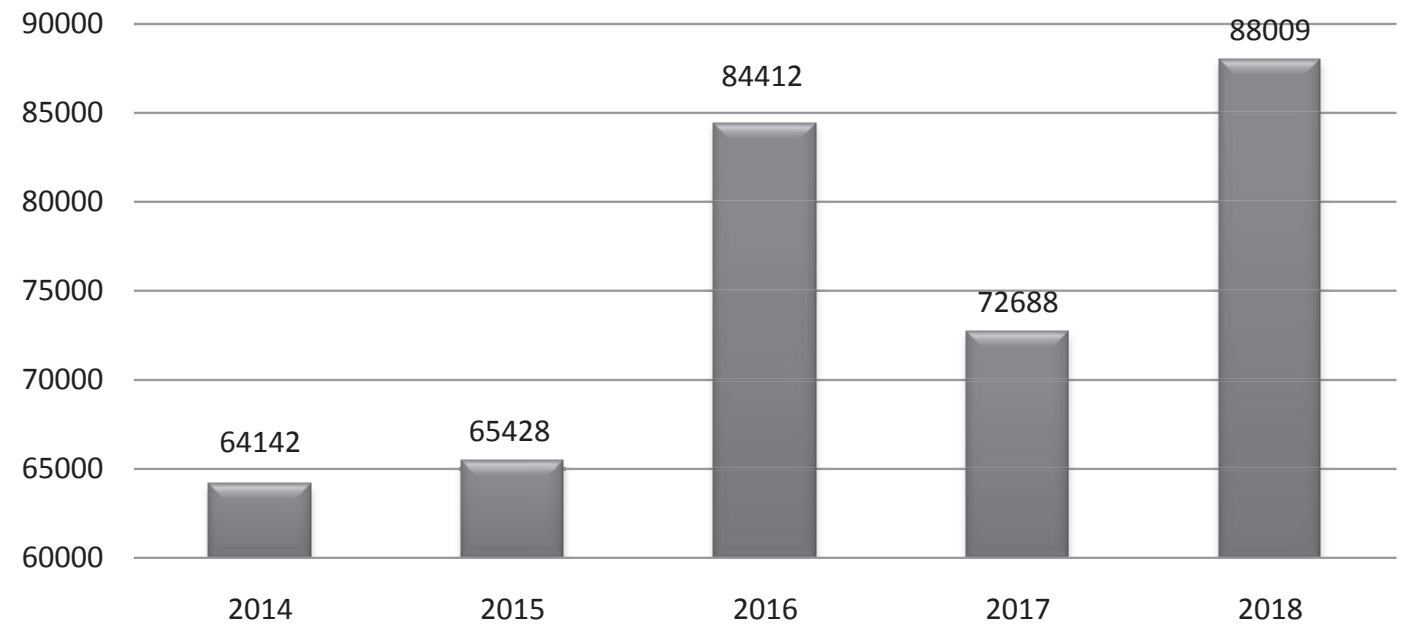

Figure4. POS (Point of Sale) $)^{5}$

\section{Payment Card Functionalityand Risks}

Transformation and transition from sliding a payment card, through holding phones or personal assistants close in order to make a payment is natural and it showsthe users the direction in which the innovations will go (Čudan, Ivanović, 2017: 93).Financial institutions are forced to follow trends in e-payment system in order to preserve their position at extremely dynamic market and in order to gain as wide a population of potential clients as possible by new services and products. The fact is that risk as a category is as old as financial

\footnotetext{
${ }^{4}$ In previous years the banks sent the information to the National Bank of Serbia as the number of POS terminals, or as one POS terminal at one selling point, while after 2016 the real number of POS terminals was shown, meaning the exact number of POS terminals considering that one selling point can have several POS terminals.

${ }^{5}$ It denotes a point of sale and in card industry it represents also an electronic device which contains a magnetic recording reader or a chip and it is necessary formaking a purchase using a payment card.
} 
operations, although risk managementis the result of new development history. Detecting possible risks, especially those in the zone of monetary destructions and crime is important, since financial institutions have primary motive to protect their business operations and thus the interest of their clients and ultimately the financial system of a country.

Classification and grouping of risks is not simple at all considering the practically inexhaustiblenumber of risk sources, particularly in criminalsphere(Balaban, 2017: 32). Every uncertainty in banking and card operations represents a risk. Identification of a risk represents a set of analytical techniques by which the elements of uncertainty can be determined (Janković, 2011: 176).

Credit card frauds can be divided into certain categories depending on who committed the fraud, who the participants in the fraud are, or the manner in which the card data were compromised and abused. In practice it is not always possible to make precise difference among individual types of abuse (Urošević, 2009: 142). In the Republic of Serbia the most common cases of payment card frauds include:

- Frauds using counterfeited cards;

- Card not present - a fraud at the Internet point of sale;

- Card not present - transactions initiated by postal order (MOTO transaction);

- Lost/stolen card.

In addition to the previously mentioned frauds that can be carried out using payment cards, there are also frauds present at the card acceptance point, in other words there are frauds that can be carried out at ATM or POS terminals which accept cards as a payment instrument (PrivrednakomoraSrbije, 2018: 54).

- ATM abuses;

- Skimming, frauds with counterfeited cards;

- Cash trapping,a fraud using special mechanical devices to capture cash illegally;

- Malware,an unauthorized access and use of malicious software at the ATM which results in giving a command for illegal cash payout;

- Gas attack, a physical attack using certain kinds of gas which areinserted into the ATM box and initiating explosion; 
- ATM theft, or taking away the entire ATM machine.

- Merchant Fraud, represents a payment card abuse by an owner of an acceptance point or some of the employees.

- The other types of frauds include:

- Card Database Breach;

- Under Floor Limit, an abuse when a card is used in the amount below the limit of a sales point in order to avoid authorization.

Replacement of banknotes coming from robberies or thefts. The current practice suggests that there is a problem of replacement of marked banknotes, which are dye-marked as a security measure from money theft (Jaracz et al., 2018). The banknotes coming from robberies or thefts are possible to replace at ATMs, because ATMs do not have sensors to detect the dye. Also there is not standardized dye used for banknote neutralization (Grondahl Lee, 2017: 113). The so called IBNS (Intelligent Banknote Neutralisation System)system is used for dying which is activated during the robbery from transport containers, bags and other transport packages. It is common to use red, purple or green dye. The problems of banks within whose network such banknotes were replaced is that they cannot replace them and therefore this represents a loss for them. Due to these reasons some business banks discontinued the function of exchange at their ATMs. The problem evidently exists in the EU countries and not much has been done to solve it so far. ${ }^{6}$

Corporate cannibalism or market cannibalism is the practice of reducing a product price or introducing a new product into the market of certain product categories, in this case payment cards. If a company is in practice of market cannibalism, it is considered to eat its own market hoping to get a larger portion of it. This phenomenon can have both positive and negative effects on the ultimate results of a company, it can be intentional or unintentional and it is called

\footnotetext{
${ }^{6}$ The European Commission has published a Recommendation 191/EU according to which the member countries should actively communicate with trading banks and the public in order to raise awareness that dye-marked banknotes must be returned to national central banks.
} 
cannibalization strategy. ${ }^{7}$ Cannibalization of a physical product into a digital product is inevitable and it should not be avoided.

Two primary reasons why card companies can resort to cannibalization of their own market share by corporate cannibalism include: gaining overall larger market share within the same product category, in this case in digital payment ecosystem, at the expense of losing its already established card product, or simply because they believe that another e-payment product would sell better than the previous one. In addition to possibly better payment than the previous product, the new product could be sold to another type of customers, which additionally highlights the increase of the total market share. The hypothesis is that by better control of innovations as a reason for market cannibalism larger profit and better social standards at the entire market can be achieved than those that can be achieved without the control and development of innovations. Research and development play crucial role in increasing market share, which is the ultimate goal of the company.

Instant paymentsrepresent currently the most up-to-date and the most user-attractive form of payment, since they make it possible to keep all the advantages of cash money and avoid the disadvantages of cash payment, in other words the possibility of abuse, high costs of cash management, grey economy and other. Such a payment concept represents a kind of approved transfer and it is carried out in a way and within the terms determined by the decision regulating the general rules of instant transfers.

Instant payment was launched in Serbia on October 22, 2018, and according to the estimate of the central monetary institution it would reduce the use of cards by about $30 \%$ in the next five years. This modern concept is the response to high card system commissions which range up to $2.2 \%$ for certain card payment services at selling points. Instant payment is competition to card payment due to lower fees in comparison with card payment commissions. This form of payment would cause tectonic changes in the payment market. Its manner of operation, functionality as well as applied technical and

\footnotetext{
${ }^{7}$ Cannibalism, Spanish Canibal-human flash eater, human flash eating, the name originating from a Spanish word for the people of Carib from the Lesser Antilles who were reputed to eat humans.
} 
technological solutions, are in accordance with the current state-of-theart trends applied in the field of instant payment systems.

Simple, safe, practical and instant - this is how we can describe this new form of payment which is entering financial practice. There are numerous advantages offered by instant payment in comparison with former payments, some of the most significant including (Narodna banka Srbije, 2018: 1):

- 24/7/365 payment from every location and using various modern telecommunication devices;

- monetary assets are available to the receiver of payment in a few seconds;

- lower transaction processing costs for small monetary values;

- possibility to create new products and services;

- potential for the service of receiving payment instruments to be dealt with those payment service providers who did not deal with such payments so far;

- reduced payment costs;

- improved cash flow management;

- new and more inexpensive payment instrument for traders, competitive to card payments.

The new manner of payment implies also new and up-to-date technology. The buyers would be able to pay for goods and servicesusing special applications on their cell phones. The NBS has specified that the instant payment at a selling point will be made using IPS QR(Instant Payments Serbia - The Quick Response) code, which will be standardized for all banks in order to enable inter-operability. ${ }^{8}$ Those offering payment services would offer their clients, both payers and traders, the applications which would enable such a payment. Introduction of instant payment, which Serbia has introduced among

\footnotetext{
${ }^{8} \mathrm{QR}$ code is a square consisting of a small mosaic of black and white small squares which can be read by a camera and translated by software into digital information. These two-dimensional codes are printed on a surface, most often paper one, but they can also be formed at a screen of another phone. In case of instant payment they contain information which a traditional money order form would contain, who is paying for what, to whom the payment is made, to which account and the amount to be paid. If you agree with what is written in it, by the touch on a screen you make a payment (with security measures used by the bank, PIN code most frequently), and the transaction is completed.
} 
the first in Europe, represents a huge step forward to even better customer experience for both clients and banks.

It is an undoubted fact that banks, due to development of social networks, will have to waive some of their current income sources. The emergence of low cost banks at social networks would also influence the decrease in prices of banking services. The entire concept is based on the solutions which are already applied at banking markets worldwide. What remains to be seen is how the banks would use new opportunities to increase their competitiveness at the market and how they will use the tools available to them by the development of social networks and what role this would give to payment cards in a new financial environment. In a period when time is money, those who opt for this form of payment would save both their time but also commissions. Speed, flexibility, lower costs and absence of time limit are the main advantages of e-banking. As for selling and marketing, innovation is a key item for survival and success at the market. The development of new digital channels is priority of banks. The rule which applies to both banks and companies in other sectors is: digital transformation starts inside. The new bank is open, agile, flexible and adaptable.

Digitalization process is the future that has already happened to us and only the institutions which understand that investing into digital communications is the imperative of their business operations can count on satisfaction and trust of their clients. The use of payment cards, then electronic and finally mobile banking suppressed counters and forms, and if we bear in mind increasingly simple and comfortable digital services, with increased security of their use, the fact that more and more clients cooperate with their banks without entering the branch offices is not surprising, and the role and function of card system enables them to do so.

\section{Legal Protection of E-Payment}

Payment cards represent a modern e-payment instrument issued by a bank, payment institution or a legally authorised organization which enable users to dispose of their assets on the account, i.e. to make payment of goods and services of to take cash or make any other operation related to the assets on the account. The basis for a payment 
card is an order for a certain amount of money to be paid or given, transferred or an order of the holder referring to a specific card characteristic (NarodnabankaSrbije, 2018: 8). A particularly significant moment when assessing formal and content-related aspect of the current legal regulations is the degree of protection of e-money and ebanking users. As it can be seen, there are numerous potential threats to e-money system and the transactions within this system. Many questions emerge related to the legal regulation of these processes.

Laws based on which the use of payment cards is regulated in Serbia are:

- The Criminal Code of the Republic of Serbia

- Law on Payment Operations

- Law on Banking and Other Financial Organizations.

Based on the Criminal Code of the Republic of Serbia all criminal offences related to counterfeiting and abuse of payment cards are laid down in Article 243 of the Law, as well as making, providing and supplying counterfeiting means to another person, in Article $244 \mathrm{~b}$ paragraph 2 of this Law. The law also sets out the corresponding penalties for crime offenders. Criminal offence of counterfeiting and abuse of payment cards used to be within the criminal offence of fraud and the criminal offence of forging a document. However, the great expansion and useof payment cardsis accompanied by their abuses so these forms of criminal offences were separated as independent criminal offences (Čudan, Nikoloska, 2018: 339). 
Table 2. Share of criminal offence of counterfeiting and abuse of payment cards, Article 243, and making, providing and supplying counterfeiting means to another person, Article 244b, in the structure of the total number of criminal offences in the area of high-tech criminal offences in the territory of the Republic of Serbia

\begin{tabular}{c|c|c|c}
\hline Year & $\begin{array}{c}\text { Number of } \\
\text { crimes in the field } \\
\text { of high-tech } \\
\text { crime }\end{array}$ & $\begin{array}{c}\text { Counterfeiting and } \\
\text { abuse of payment } \\
\text { cards Art. 243 }\end{array}$ & $\begin{array}{c}\text { Making, providing } \\
\text { and supplying } \\
\text { counterfeiting means } \\
\text { to another person } \\
\text { Art. 244b }\end{array}$ \\
\hline 2011 & 873 & 666 & 0 \\
\hline 2012 & 624 & 430 & 0 \\
\hline 2013 & 855 & 605 & 3 \\
\hline 2014 & 780 & 481 & 2 \\
\hline 2015 & 663 & 403 & 2 \\
\hline 2016 & 703 & 380 & 0 \\
\hline 2017 & 768 & 413 & 2 \\
\hline 2018 & 662 & 177 & \\
\hline
\end{tabular}

Source: Ministry of Interior of the Republic of Serbia.

Analysing criminal-law framework of counterfeiting and abuse of payment cards both in Serbia and the countries of the Western Balkans, there is generally an adequate legal framework. However, for efficient protection and suppression of this crime it is not sufficient to have an adequate criminal-law framework, but it is necessary first of all to raise awareness of card users of the necessity to know certain forms of protection on the one hand, and it is also necessary to educate the police and judiciary on the other hand, considering that this is a specific type of crime within which various technical and technological knowledge is used (Babović, 2018: 72).

What we have to remark in this last chapter, in which we discuss the most important legal issues related to this field, is that legal solutions, no matter how much they are extensive and duly updated in their content can never fully accompany the events in reality. It has been known for a long time that no matter how many efforts the legislator makes a large number of institutes in positive legal regulations are not covered or they are covered by a segment smaller 
than required. This is particularly characteristic in the area of information and communication technologies. Positive legal regulations in this field appeared only in a few recent years and are present in just a few legal regulations. E-business requires a high degree of protection from abuses by fulfilling legal and technical requirements. Adequate application of legal framework would reduce the risks related to securing the data in order to protect privacy and secrecy of information systems, as well as those related to possibility of abuse. The relationship between e-money and real money is the question which deserves special attention from macroeconomic aspect.

Adopting the Law on E-trade, as well as the Law on Payment Operations the legal basis has been created to make e-business equal to the traditional one and this is the basis to develop e-business and therefore the general economic development of Serbia as well. Today in the conditions of developed global e-trade the consumers are faced with numerous challenges in the form of huge amount of information, numerous financial frauds, misrepresentation, deceits, etc. The fact is that the risks have increased together with the development of etrade.Transnationality of e-money and e-payment is the topic with which both economic and legal sciences deal. Economic consequences of e-payment have not yet been examined sufficiently and the legal regulations are trying to define the business operations framework. Economic consequences of e-money and e-payment are multiple.

\section{Conclusion}

In the contemporary conditions there is an increasing number of financial transactions and payments which are carried out in the environment relaxed from limited physical presence of people. Developed economy and finances, traditionally turned towards cash money at the beginning of the new millennium dynamically divert focus of interest to various payment systems. It is undoubted that digitalization trends influence financial flows, and therefore many products and services, so payment cards and their architecture have found their place in the ecosystem of payments despite the risks they entail.

Possible disadvantages in security and safety of payment cards have been reduced to an ultimately reasonable measure, which primarily refers to card-holder mistakes. Creators of monetary policy 
prompt all participants in this kind of payment to constantly develop and legal regulations are obliged to follow the technological innovation in the payment field.

It is clear that the greatest technological achievement in banking development is emergence of e-money, which automatically and preferably singled out the sector of e-banking. In this paper, inspired by modern trends and orientations in business operations, we have tackled the current issues related to e-money and e-banking. We have considered their accompanying risks, forms, factors influencing their development as well as economic effects and legal aspects of the entire process of card payment system. We conclude that such an approach to business operations, despite certain dilemmas or shortcomings, if considered from economic or legal aspect, has many advantages when compared with traditional business operations: reduction of transaction costs; faster circulation of assets; safe and secure payment operations; time saving; possibility to make transactions from a workplace, as well as constant insight into the balance on the account and transactions.

\section{References}

1. Balaban N., Ristić Ž., Đurković J., Trninić J., Tumbas P. (2007), Informacione tehnologije i informacioni sistemi, Ekonomski fakultet Subotica.

2. Babović S. (2018), Krivično delo falsifikovanja i zloupotrebe platnih kartica u zakonodavstvu Republike Srbije i državama Zapadnog Balkana, Pravo teorija ipraksa, 7-9, 62-74.

3. Čudan A., Nikoloska S. (2018), Ekonomski kriminal, Kriminalističko-policijski univerzitet, Beograd.

4. Čudan A., Ivanović Z. (2017), The Ninth International Conference on Business Information Security BISEC, Beograd, 93-103.

5. Granville V. (2017), A Guide to Data Science for Fraud Detection Posted.

6. Janković S. (2011), Falsifikovanje platnih kartica, kao pojavni oblik kompjuterskog kriminala, Bezbednost, 1/2011, 176-189.

7. Jaracz J. (2018), Card Fraud and Card Declines Not Uncommon, London. 
8. Končar J. (2008), Elektronska trgovina, Ekonomski fakultet u Subotici, Subotica.

9. Lazović V., Đuričković T. (2018), Digitalna ekonomija, Naciobalna bibljoteka Crne Gore, Cetinje.

10. Lee J. G., Scott G. G. (2017), Preventing Credit Card Fraud: A Complete Guide for Everyone from Merchants to Consumers, London.

11. Narodna banka Srbije (2018), Sistem za instant plaćanja, Beograd, 1-8.

12. Privredna komora Srbije (2018), Platne kartice, Beograd, 1-106.

13. Urošević V. (2009), Nigerijska prevara u Republici Srbiji, Bezbednost, 3/2009, 142-161.

\section{Nova arhitektura i rizici u poslovanju sa platnim karticama}

Apstrakt: Digitalizacija u svim sferama društvenog života, velika rasprostranjenost i mogućnosti ,pametnih" telefona i sve veća zastupljenost elektronskih sadržaja, usluga, dovodi do pojave novih očekivanja i novih zahteva banaka, kupaca i prodavaca, koji se odnose na savremenu arhitekturu poslovanja sa platnim karticama. Plaćanja su sastavni deo poslovnih operacija, bez obzira da li se radi o tradicionalnom ili onlajn poslovanju, te je iz tih razloga neophodno pronaći najbolji način da se plati za dobra ili uslugu uz korišćenje novih tehnoloških i komunikacionih rešenja.

Predmet istraživanja u radu je analiza karakteristika savremenih rizika, faktora razvoja, ekonomskih efekata i zastupljenosti platnih kartica u sistemu elektronskog novca, plaćanja i elektronskog bankarstva, sa ciljem da ukažemo na moguće pozitivne ekonomske posledice $i$ neophodnost inoviranja $i$ upotpunjavanja zakonske regulative u ovoj oblasti.

U radu su korišćene opšte kao i posebne naučne metode i postupci logičnog zaključivanja, statistički, kao i pozitivistički pravni metod. Način istraživanja sadrži: izbor $i$ primenu naučnih metoda, izbor podataka i obuhvat istraživanja.

Ključne reči: platne kartice, rizik, plaćanje, bezbednost 